\title{
Visible light-driven oxygen evolution using a binuclear Ru-bda catalyst
}

\author{
Fei Li a,*, Congying Xu a, Xiaohong Wang a, Yong Wang a, Jian Du a, Licheng Sun a,b \\ a State Key Laboratory of Fine Chemicals, DUT-KTH Joint Education and Research Center on Molecular Devices, Dalian University of Technology (DUT), \\ Dalian 116024, Liaoning, China \\ b Department of Chemistry, School of Chemical Science and Engineering, KTH Royal Institute of Technology, 10044 Stockholm, Sweden
}

\section{A R T I C L E I N F}

\section{Article history:}

Received 17 October 2017

Accepted 6 January 2018

Published 5 March 2018

\section{Keywords:}

Water oxidation

Binuclear ruthenium catalyst

Photocatalysis

Solvent effect

Kinetics

\begin{abstract}
A B S T R A C T
Binuclear ruthenium complexes bearing the 2,2'-bipyridine-6,6'-dicarboxylate (bda) ligand have been demonstrated to be highly active catalysts towards water oxidation with $\mathrm{Ce}^{\mathrm{IV}}$ as an oxidant. However, the catalytic properties of ruthenium dimers have not yet been explored for visible light-driven water oxidation. Herein, the photocatalytic performance of a dipyridyl propane-bridged ruthenium dimer 2 was investigated in comparison with its monomeric precursor, [Ru(bda)(pic) 2 ] (1), in $\mathrm{CH}_{3} \mathrm{CN}$ /phosphate buffer mixed solvent in a three-component system including a photosensitizer and a sacrificial electron acceptor. Experimental results showed that the activity of each catalyst was strongly dependent on the content of $\mathrm{CH}_{3} \mathrm{CN}$ in the phosphate buffer, which not only affected the driving force for water oxidation, but also altered the kinetics of the reaction, probably through different mechanisms associated with the 0-0 bond formation. As a result, dimer 2 showed significantly higher activity than monomer 1 in the solvent containing a low content of $\mathrm{CH}_{3} \mathrm{CN}$, and comparable activities were attained with a high content of $\mathrm{CH}_{3} \mathrm{CN}$ in the solvent. Under the optimal conditions, complex 2 achieved a turnover number of 638 for photocatalytic $\mathrm{O}_{2}$ evolution.
\end{abstract}

(C) 2018, Dalian Institute of Chemical Physics, Chinese Academy of Sciences. Published by Elsevier B.V. All rights reserved.

\section{Introduction}

Artificial photosynthesis represents a sustainable approach toward conversion of solar energy into chemical fuels, for example, the production of hydrogen via water splitting [1,2]. The overall water splitting reaction consists of two half reactions, namely, water oxidation and proton reduction [3]. Oxidation of water is generally considered to be a difficult transformation because of the requirement of multiple electron transfer processes coupled with the removal of multiple protons from water molecules, which altogether impose a great challenge to artificial photosynthesis [4,5]. While numerous heterogeneous and homogeneous catalysts have been developed to facilitate the oxygen evolution from water, most of them suffer from slow reaction rate and low stability [6-10]. In comparison with the conventional heterogeneous metal oxide catalysts, molecular water oxidation catalysts (WOCs) based on transition metal complexes have shown advantages in structural tunability and ease of mechanistic studies $[6,11]$. Since the first molecular WOC cis,cis-[(bpy $\left.)_{2}\left(\mathrm{H}_{2} \mathrm{O}\right) \mathrm{Ru}(\mu-\mathrm{O}) \mathrm{Ru}\left(\mathrm{H}_{2} \mathrm{O}\right)(\mathrm{bpy})_{2}\right]^{4+} \quad(\mathrm{bpy}=$ 2,2'-bipyridine) (blue dimer) was reported in 1982 [12], numerous efforts have been made to enhance the activity of molecular WOCs [13], Recently, Sun and co-workers[14] developed a series of mononuclear ruthenium catalysts based on

\footnotetext{
* Corresponding author. Tel: +86-411-84986247; Fax: +86-411-84986245; E-mail: lifei@dlut.edu.cn

This work was supported by the National Basic Research Program of China (973 Program, 2014CB239402), the National Natural Science Foundation of China (21476043), the Fundamental Research Funds for the Central Universities (DUT17ZD204), and the Swedish Energy Agency and K\&A Wallenberg Foundation.
}

DOI: 10.1016/S1872-2067(18)63024-4 | http://www.sciencedirect.com/science/journal/18722067 | Chin. J. Catal., Vol. 39 , No. 3, March 2018 
2,2'-bipyridine-6,6'-dicarboxylic acid (bda) ligand, which exhibited superior water oxidation activity in comparison to previously reported WOCs. Kinetic and DFT calculations revealed a bimolecular radical coupling mechanism of the $\mathrm{O}-\mathrm{O}$ bond formation during the catalytic cycle $[15,16]$. Based on this understanding, we developed a class of dinuclear ruthenium catalysts, [(4-pic)(bda)Ru ${ }^{\mathrm{II}}\left(\mu\right.$-L)Ru ${ }^{\mathrm{II}}(\mathrm{bda})(4-$ pic)] (pic = picoline, $\mathrm{L}=$ bridge ligand), by covalently connecting two mononuclear units with organic bridge ligands. Using this strategy, the $\mathrm{O}-\mathrm{O}$ bond formation changed from an intermolecular manner to a more facile intramolecular manner, resulting in the greatly enhanced activity over that of the mononuclear species, especially at low catalyst concentrations [17].

However, the systems mentioned above are driven by either a chemical oxidant or electric power, and the visible-light induced water oxidation is less studied despite its fundamental importance to solar fuel utilization [18-24]. Specifically, the performance of the bda-based ruthenium dimer in photocatalytic water oxidation has not yet been fully explored, even though these complexes demonstrate highly efficient $\mathrm{O}_{2}$ evolution with TONs $>10000$ in chemical water oxidation with $\left(\mathrm{NH}_{4}\right)_{2} \mathrm{Ce}\left(\mathrm{NO}_{3}\right)_{6}$ as the oxidant [17]. To fill this gap, in this work, we have discussed the photocatalytic water oxidation activity of a binuclear ruthenium complex [(4-pic)(bda)Ru ${ }^{\mathrm{II}}\left(\mu\right.$-L)Ru $\left.{ }^{\mathrm{II}}(\mathrm{bda})(4-p i c)\right]$ (L = 1,3-(dipyridin-4-yl) propane, 2) under visible light irradiation. The performance of 2 was compared with that of the monomeric complex $\left[\mathrm{Ru}^{\mathrm{II}}(\mathrm{bpa})(\mathrm{pic})_{2}\right]$ (1). In addition, a dependence of the reaction mechanism on the reaction solvent has been discussed.

\section{Experimental}

\subsection{Equipment}

${ }^{1} \mathrm{H}$ NMR spectra were collected at $298 \mathrm{~K}$ using a Bruker DRX-400 instrument. Electrospray ionization mass spectra and high-resolution mass spectra were recorded on a Q-Tof Micromass spectrometer (Manchester, England). UV-Vis absorption measurements were carried out on an Agilent 8453 spectrophotometer. Oxygen evolution were analyzed on a Techcomp GC 7890T instrument equipped with a $5 \AA$ molecular sieve column and a thermal conductivity detector with argon as the carrier gas. The electrochemical measurements were recorded on a CHI 660D electrochemical potentiostat. The light power was measured with a CEL-NP 2000 laser power meter.

\subsection{Synthesis of complexes $\mathbf{1}$ and $\mathbf{2}$}

Ruthenium complexes $\mathbf{1}$ and $\mathbf{2}$ were prepared according to previously reported procedures and characterized by ${ }^{1} \mathrm{H}$ NMR and mass spectrometry [17]. The synthesis of all ruthenium complexes in this study were performed under $\mathrm{N}_{2}$ atmosphere. The solvents were purified by standard methods. All other chemicals were used as received.

\subsection{Photocatalytic water oxidation}

In a typical experiment, $\left[\mathrm{Ru}(\mathrm{bpy})_{3}\right] \mathrm{Cl}_{2}(1 \mathrm{mmol} / \mathrm{L}), \mathrm{Na}_{2} \mathrm{~S}_{2} \mathrm{O}_{8}$ $(10 \mathrm{mmol} / \mathrm{L})$, and the ruthenium catalyst $(20 \mu \mathrm{mol} / \mathrm{L}$ for $\mathbf{1}$ and $10 \mu \mathrm{mol} / \mathrm{L}$ for 2 ) dissolved in the phosphate buffer solution (5 $\mathrm{mL}, \mathrm{pH}=6.8$ ) with a desired amount of $\mathrm{CH}_{3} \mathrm{CN}$ were added to a 50-mL Schlenk flask. Prior to the photo-reaction, the solution was degassed with Ar for $20 \mathrm{~min}$. The reaction was initiated by irradiation with a 300-W Xe lamp ( $\lambda>400 \mathrm{~nm}$; UV filter) under $\mathrm{Ar}$ atmosphere and at room temperature. The amount of generated $\mathrm{O}_{2}$ was quantified by gas chromatography (TCD, MS-5A) at time intervals of $5 \mathrm{~min}$.

\subsection{Cyclic voltammetry measurements}

Cyclic voltammetry measurements were obtained using a three-electrode setup with a glassy carbon (GC) working electrode, $\mathrm{Ag} / \mathrm{AgCl}$ reference electrode, and a platinum wire counter electrode. For accurate evaluation, ferrocene was added as an internal standard. Cyclic voltammograms were obtained in phosphate buffer solutions $(\mathrm{pH}=6.8$ ) containing a specified amount of $\mathrm{CH}_{3} \mathrm{CN}$. The potentials were reported versus $\mathrm{Fc}^{+} / \mathrm{Fc}$.

\subsection{Kinetic study experiments}

In a typical experiment, different amounts of $\mathbf{1}$ and $\left[\mathrm{Ru}^{\mathrm{III}}\right.$ (bpy) $\left.]_{3}\right]^{3+}(0.125 \mathrm{mmol} / \mathrm{L})$ were added into $2 \mathrm{~mL}$ of $5 \%$ or $60 \%$ $\mathrm{CH}_{3} \mathrm{CN}$ aqueous solution, and the changes in the UV-Vis absorbance of $\left[\mathrm{Ru}^{\mathrm{II}}(\mathrm{bpy})_{3}\right]^{2+}$ at $450 \mathrm{~nm}$ were recorded. The observed reaction rates ( $k_{\mathrm{obs}}$ ) at various concentrations of $\mathbf{1}$ were obtained according to the absorbance curves at $450 \mathrm{~nm}$. A linear fitting of $k_{\text {obs }}$ with [1] $]^{2}$ in $5 \% \mathrm{CH}_{3} \mathrm{CN}$ indicated second order kinetics and a linear fitting of $k_{\text {obs }}$ with [1] in $60 \% \mathrm{CH}_{3} \mathrm{CN}$ suggested that first order kinetics was operative.

\subsection{Determination of quantum efficiency}

In a typical experiment, $\left[\mathrm{Ru}(\mathrm{bpy})_{3}\right] \mathrm{Cl}_{2}(1 \mathrm{mmol} / \mathrm{L}), \mathrm{Na}_{2} \mathrm{~S}_{2} \mathrm{O}_{8}$ (10 mmol/L), and ruthenium catalyst $1(20 \mu \mathrm{mol} / \mathrm{L})$ dissolved in phosphate buffer solution $(5 \mathrm{~mL}, \mathrm{pH}=6.8$ ) containing $60 \%$ $\mathrm{CH}_{3} \mathrm{CN}$ were added to a $50 \mathrm{~mL}$ Schlenk flask. The solution was degassed using Ar for 20 min and then irradiated by a monochromatic light source $(\lambda=450 \mathrm{~nm})$. The light power $(P)$ was modulated to reach an optical density of 14 for the reaction solution. Under these conditions, the light entering the reaction solution was considered to be fully absorbed by the photosensitizers according to the Beer-Lambert law. The values of $P$ were measured with a CEL-NP 2000 laser power meter at a point right in front of the reactor. The amount of generated $\mathrm{O}_{2}$ $\left(\mathrm{nO}_{2}\right)$ was quantified by gas chromatography (TCD, MS-5A) in the first $15 \mathrm{~min}$ of the reaction. The number of moles of photons absorbed $\left(n_{\mathrm{p}}\right)$ were determined by the following equation.

$$
n_{\mathrm{p}}=P t \lambda / N_{\mathrm{A}} h c
$$

where $P$ is the absorbed power of the light (W), and $t$ is the irradiation time (900 s). The parameter $\lambda$ refers to the irradiation wavelength $(450 \mathrm{~nm}), N_{\mathrm{A}}$ is the Avogadro constant (6.022 $\left.\times 10^{23} \mathrm{~mol}^{-1}\right), h$ is the Planck constant $\left(6.63 \times 10^{-34} \mathrm{~J} \cdot \mathrm{s}\right)$, and $c$ is the speed of the light $\left(3 \times 10^{8} \mathrm{~m} / \mathrm{s}\right)$. The quantum yield, $\Phi$ was evaluated by the following equation. 

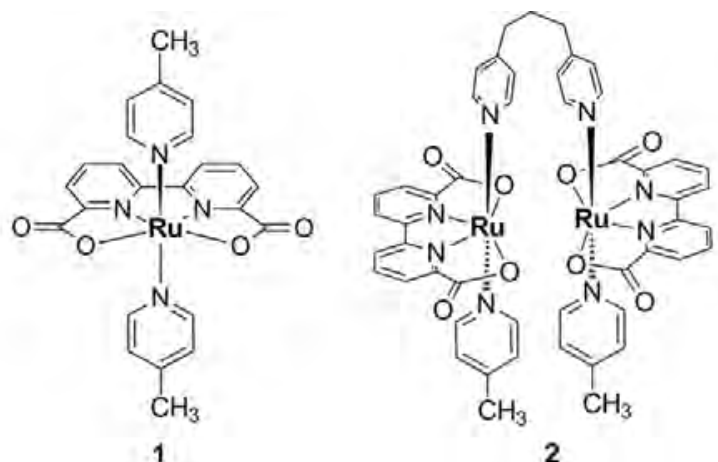

Fig. 1. Molecular structures of catalysts 1 and 2 .

$$
\Phi=n_{O_{2}} / n_{\mathrm{p}}
$$

The quantum efficiency $(Q E)$ was derived from the quantum yield of $\mathrm{O}_{2}$ as follows.

$$
Q E=\left(\Phi / \Phi_{\max }\right) \times 100 \%
$$

where $\Phi$ is the experimental value and $\Phi_{\max }$ is the theoretical maximum value. In the $\left[\mathrm{Ru}(\mathrm{bpy})_{3}\right]^{2+} / \mathrm{S}_{2} \mathrm{O}_{8}{ }^{2-}$ system, $\Phi_{\max }$ is 0.5 because two photons are needed to produce one oxygen molecule. Therefore, $Q E$ could be described as $Q E=2 \times \Phi \times 100 \%$.

\section{Results and discussion}

The visible light-driven water oxidation was carried out in a homogeneous three-component system with $\left[\mathrm{Ru}(\mathrm{bpy})_{3}\right] \mathrm{Cl}_{2}$ as the photosensitizer, $\mathrm{Na}_{2} \mathrm{~S}_{2} \mathrm{O}_{8}$ as the sacrificial electron acceptor, and either complex $\mathbf{1}$ or $\mathbf{2}$ as the catalyst [25]. The phosphate buffer solutions $(\mathrm{pH}=6.8)$ containing different amounts of $\mathrm{CH}_{3} \mathrm{CN}$ were used as the solvents for photocatalysis. The addition of $\mathrm{CH}_{3} \mathrm{CN}$ was necessary to improve the solubility of the catalyst and achieve a high activity. In such a three-component system, the ground state $\left[\mathrm{Ru}(\mathrm{bpy})_{3}\right]^{2+}$ was excited to its excited state, and $\left[\mathrm{Ru}(\mathrm{bpy})_{3}\right]^{3+}$ was subsequently generated by electron transfer from $\left[\mathrm{Ru}(\text { bpy })_{3}\right]^{2+*}$ to $\mathrm{Na}_{2} \mathrm{~S}_{2} \mathrm{O}_{8}$. As a strong oxidant, $\left[\mathrm{Ru}(\mathrm{bpy})_{3}\right]^{3+}$, in turn, accepted an electron from the catalyst. Once sufficient oxidative equivalents were accumulated at the active site of the catalyst, water was oxidized to molecular oxygen.

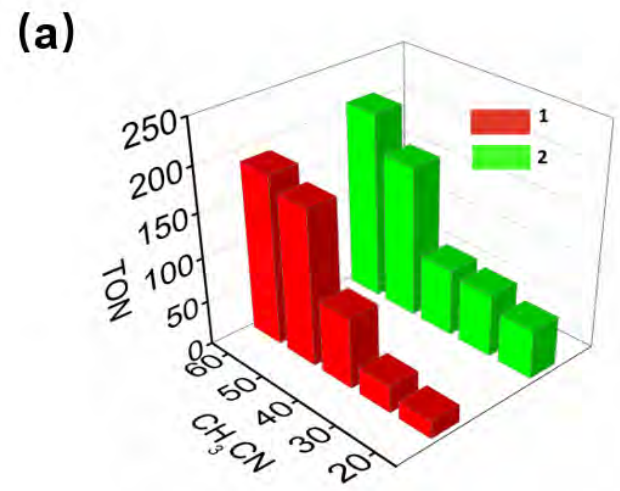

In Fig. 2(a), the TONs of oxygen evolution under visible light irradiation are plotted with respect to the volume percentage (\%) of $\mathrm{CH}_{3} \mathrm{CN}$ in phosphate buffer. This plot is associated with two important features. First, the oxygen evolution for both catalysts increased with a higher $\mathrm{CH}_{3} \mathrm{CN}$ content in the phosphate buffer. For instance, a TON of 19 was obtained for $\mathbf{1}$ in the presence of $20 \% \mathrm{CH}_{3} \mathrm{CN}$, which increased 10 times to a TON of 204 in the presence of $60 \% \mathrm{CH}_{3} \mathrm{CN}$. Likewise, the TON increased from 57 to 215 when 2 was employed as the catalyst. Another notable feature in Fig. 2(a) is that catalyst $\mathbf{2}$ exhibits higher activities than 1 in the solvents containing less $\mathrm{CH}_{3} \mathrm{CN}$, although the activities of both catalysts became comparable in solvents containing more than $40 \% \mathrm{CH}_{3} \mathrm{CN}$. Under the optimal conditions $\left(60 \% \mathrm{CH}_{3} \mathrm{CN}\right)$, a quantum efficiency of $77 \%$ was attained with irradiation at $450 \mathrm{~nm}$ for water oxidation catalyzed by $\mathbf{2}$, which is comparable to the best value reported in the literature [26]. It was found that acetonitrile not only promoted the amount of evolved oxygen, but also accelerated the reaction rate. As shown in Fig. 2(b), the photocatalytic rate of complex 2 increased from 0.07 to 0.33 /s upon increasing the content of $\mathrm{CH}_{3} \mathrm{CN}$ in the phosphate buffer from $20 \%$ to $60 \%$.

With complex 2 as the catalyst, the effect of varying $\mathrm{Na}_{2} \mathrm{~S}_{2} \mathrm{O}_{8}$ concentrations on photocatalytic water oxidation was studied in phosphate buffer containing $60 \% \mathrm{CH}_{3} \mathrm{CN}(\mathrm{pH}=6.8)$ while keeping the concentrations of $2\left(10 \mu \mathrm{mol} / \mathrm{L}\right.$ and $\left[\mathrm{Ru}(\mathrm{bpy})_{3}\right] \mathrm{Cl}_{2}$ ( $1 \mathrm{mmol} / \mathrm{L})$ constant. The highest activity based on TON was obtained in the presence of $45 \mathrm{mmol} / \mathrm{L} \mathrm{Na}_{2} \mathrm{~S}_{2} \mathrm{O}_{8}$. When the concentrations of $\left[\mathrm{Ru}(\mathrm{bpy})_{3}\right] \mathrm{Cl}_{2}$ and $\mathrm{Na}_{2} \mathrm{~S}_{2} \mathrm{O}_{8}$ were fixed, lowering the concentration of the catalyst also lowered the amount of evolved oxygen, but the corresponding TONs were increased. For example, a TON of 638 was obtained under the reaction condition of $45 \mathrm{mmol} / \mathrm{L} \mathrm{Na}_{2} \mathrm{~S}_{2} \mathrm{O}_{8}, 1 \mathrm{mmol} / \mathrm{L}\left[\mathrm{Ru}(\mathrm{bpy})_{3}\right] \mathrm{Cl}_{2}$, and $2 \mu \mathrm{mol} / \mathrm{L}$ catalyst.

In order to clarify the role of $\mathrm{CH}_{3} \mathrm{CN}$ in promoting photocatalytic activity, the cyclic voltammetry (CV) of the photosensitizer $\left[\mathrm{Ru}(\mathrm{bpy})_{3}\right] \mathrm{Cl}_{2}$ was carried out in phosphate buffers with varying amounts of $\mathrm{CH}_{3} \mathrm{CN}$. As shown in Fig. 3(a), the onset potential for water oxidation was negatively shifted with the increase in $\mathrm{CH}_{3} \mathrm{CN}$ content in the mixed solvent. For example, the onset potential of oxygen evolution decreased by $82.5 \mathrm{mV}$

\section{(b)}

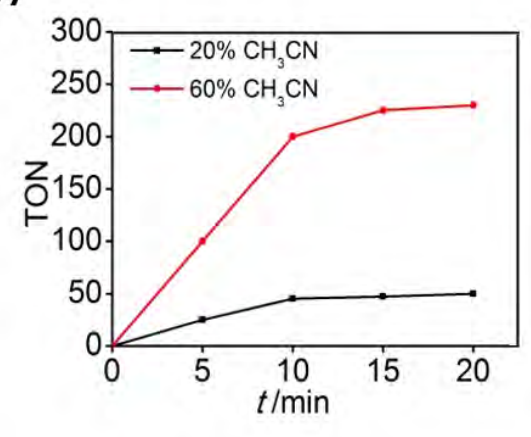

Fig. 2. (a) Photocatalytic oxygen evolution by complexes $1(20 \mu \mathrm{mol} / \mathrm{L})$ and $2(10 \mu \mathrm{mol} / \mathrm{L})$ in phosphate buffer (pH = 6.8) containing different amounts of $\mathrm{CH}_{3} \mathrm{CN}$; (b) Oxygen evolution-time plots of photocatalytic oxygen evolution by 2 (10 $\mu$ mol/L) in phosphate buffers containing $20 \%$ and $60 \% \mathrm{CH}_{3} \mathrm{CN}$, respectively. All experiments were conducted in the presence of $1 \mathrm{mmol} / \mathrm{L} \mathrm{Ru}(\mathrm{bpy})_{3} \mathrm{Cl}_{2}$ and $10 \mathrm{mmol} / \mathrm{L} \mathrm{Na} \mathrm{S}_{2} \mathrm{O}_{8}$ under visible light irradiation. 

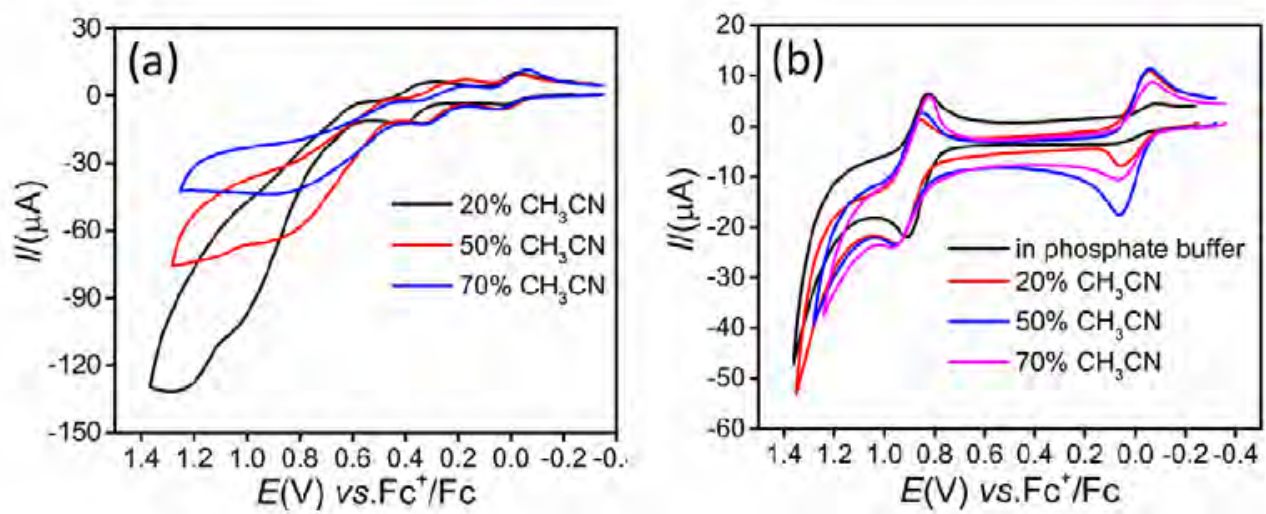

Fig. 3. (a) CVs of complex 1 in phosphate buffers containing (20-70) $\% \mathrm{CH}_{3} \mathrm{CN}$; (b) $\mathrm{CVs}$ of $\left[\mathrm{Ru}(\mathrm{bpy})_{3}\right] \mathrm{Cl}_{2}$ in phosphate buffers containing different amounts of $\mathrm{CH}_{3} \mathrm{CN}(0-70) \%$. The potentials are reported versus $\mathrm{Fc}^{+} / \mathrm{Fc}$, which was used as an internal standard. Scan rate $0.1 \mathrm{~V} / \mathrm{s}$. Complex 1 was insoluble in pure phosphate buffer.

in an aqueous solution containing $50 \% \mathrm{CH}_{3} \mathrm{CN}$ in comparison with that in phosphate buffer containing $20 \% \mathrm{CH}_{3} \mathrm{CN}$. In contrast, the redox potential of the photosensitizer $\left[\mathrm{Ru}(\mathrm{bpy})_{3}\right]^{3+/ 2+}$ $\left(E_{1 / 2}\right)$ was not influenced by the content of $\mathrm{CH}_{3} \mathrm{CN}$ in the reaction solution (Fig. 3(b)). Since $\left[\mathrm{Ru}(\mathrm{bpy})_{3}\right]^{3+}$ serves as a strong oxidant in photocatalysis, increasing the proportion of $\mathrm{CH}_{3} \mathrm{CN}$ in the mixed solvent could increase the driving force for water oxidation, leading to higher activity for oxygen evolution [27]. This analysis agrees well with our observation that the TON increases with the increase in the relative content of $\mathrm{CH}_{3} \mathrm{CN}$ in the phosphate buffer (Fig. 2(a)).
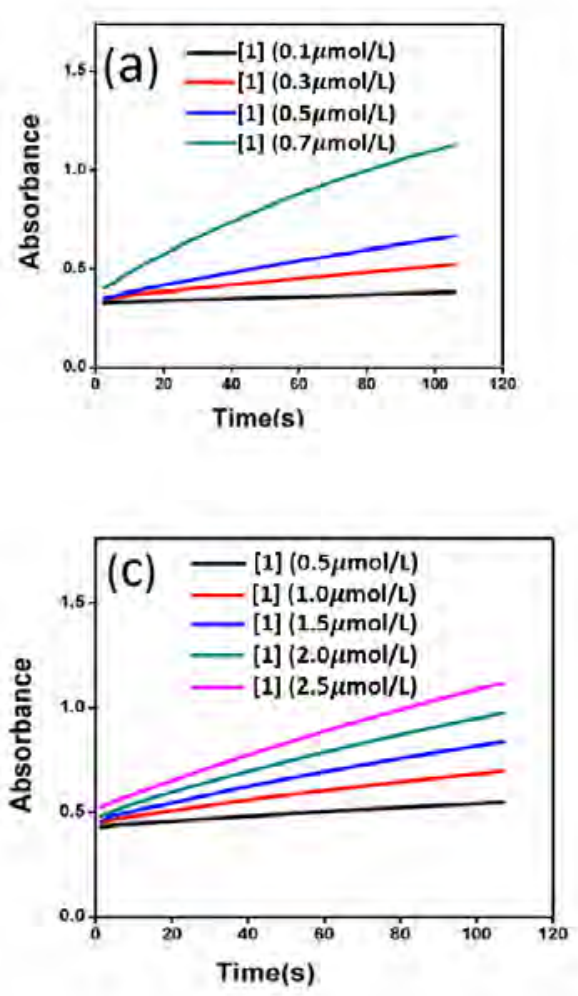

In another experiment, $\left[\mathrm{Ru}(\mathrm{bpy})_{3}\right]^{3+}$ was separately synthesized as a chemical oxidant to facilitate the kinetic study of water oxidation. The UV-Vis absorption changes at $450 \mathrm{~nm}$ were monitored upon addition of different concentrations of $\left[\mathrm{Ru}(\mathrm{bda})(\mathrm{pic})_{2}\right]$ into $2 \mathrm{~mL}$ of $\left[\mathrm{Ru}(\mathrm{bpy})_{3}\right]^{3+}(0.125 \mathrm{mmol} / \mathrm{L})$ phosphate buffer solutions containing either $5 \%$ or $60 \%$ $\mathrm{CH}_{3} \mathrm{CN}$. Based on the absorption-time plots shown in Fig. 4(a) and (c), $k_{\text {obs }}$ was estimated as a function of catalyst concentration (Fig. 4(b) and (d)).

The value of $k_{\text {obs }}$ was found to be proportional to the square of the concentration of $\mathbf{1}$ in $5 \% \mathrm{CH}_{3} \mathrm{CN}$ aqueous solution (Fig.
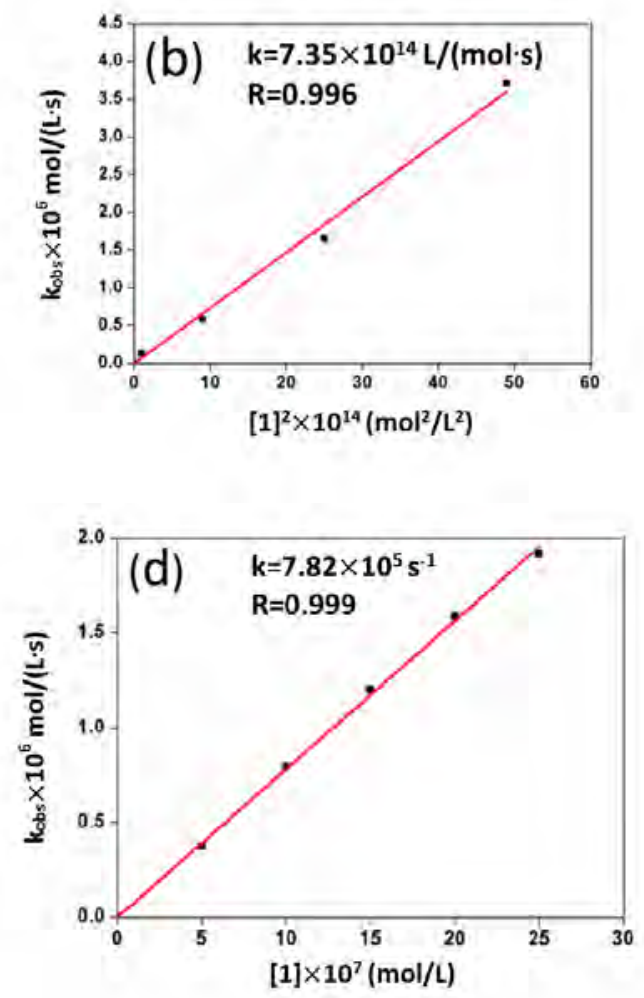

Fig. 4. Absorbance changes monitoring at $450 \mathrm{~nm}$ after the addition of $\left[\mathrm{Ru}(\mathrm{bpy})_{3}\right]^{3+}(0.125 \mathrm{mmol} / \mathrm{L})$ and different amount of $\mathbf{1}$ into $5 \%(\mathrm{a})$ and $60 \%$ (c) $\mathrm{CH}_{3} \mathrm{CN}$ aqueous solution; (b) $k_{\mathrm{obs}}$ as a function of [1] $]^{2}$ in $5 \% \mathrm{CH}_{3} \mathrm{CN}$ solution; (d) $k_{\mathrm{obs}}$ as a function of [1] in $60 \%$ CH $3 \mathrm{CN}$ solution. 

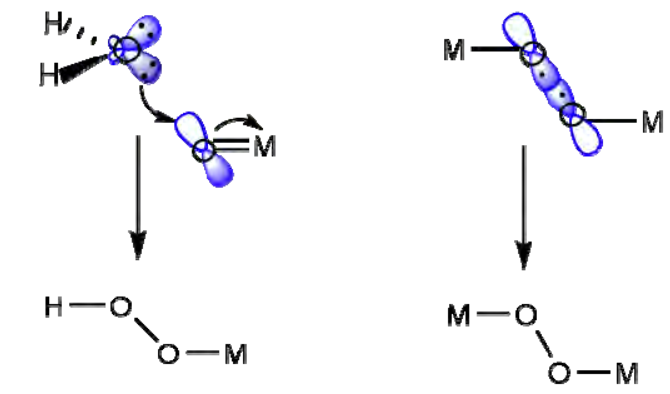

Water nucleophilic attack

Bimolecular radical coupling

Fig. 5. Two possible reaction mechanisms involved in catalytic water oxidation.

4(b)), which was indicative of second order kinetics involving two catalyst molecules in the rate-determining step. This feature is consistent with a radical coupling mechanism as previously reported $[16,25]$. In comparison, $k_{\text {obs }}$ showed a linear dependence on the concentration of 1 in $60 \% \mathrm{CH}_{3} \mathrm{CN}$ solution, indicating first order kinetics with a single catalyst molecule in the rate-determining step [28]. Therefore, water oxidation in $5 \%$ and $60 \% \mathrm{CH}_{3} \mathrm{CN}$ solution may be governed by different reaction mechanisms.

On the basis of the manner of $\mathrm{O}-\mathrm{O}$ bond formation, it was concluded that two different kinds of mechanisms were prevalent [29]. The first mechanism is the aforementioned bimolecular radical coupling, wherein oxygen is released through the interaction between two $\mathrm{M}=0(\mathrm{M}=\mathrm{Ru}, \mathrm{Ir}, \mathrm{Fe}, \mathrm{Co}, \mathrm{Mn}$, and so on) moieties. The second mechanism involves the nucleophilic attack of the water molecule on the single site of the $\mathrm{M}=0$ intermediate to release molecular oxygen via the $\mathrm{M}-\mathrm{OOH}$ peroxide (Fig. 5). It is highly plausible that the reaction mechanism alters from intermolecular radical coupling to water nucleophilic attack upon increasing the relative content of $\mathrm{CH}_{3} \mathrm{CN}$. This assumption explains the trend observed in Fig. 2(a) that the catalytic activities of $\mathbf{1}$ and $\mathbf{2}$ only differ in the mixed solvent with a low content of $\mathrm{CH}_{3} \mathrm{CN}$, which become comparable in the solvent with a high content of $\mathrm{CH}_{3} \mathrm{CN}$. However, the possibility that the rate-determining step in the radical coupling pathway switches from $\mathrm{O}-\mathrm{O}$ bond formation to a step that involves association with one Ru center cannot be excluded. The active intermediate of water oxidation in a mixed solvent of $\mathrm{CD}_{3} \mathrm{CN} / \mathrm{D}_{2} \mathrm{O}(7 / 3 \mathrm{~V} / \mathrm{V})$ was characterized by mass spectrometry and ${ }^{1} \mathrm{H}$ NMR spectroscopy as $\left[\mathrm{Ru}(\mathrm{bda})(\mathrm{pic})_{2}(\mathrm{OH})\right]^{+}$, a seven-coordinate $\mathrm{Ru}(\mathrm{IV})(S$ $=0$ ) species, consistent with that isolated in our previous study [14]. The subsequent one electron oxidation of $\left[\mathrm{Ru}^{\mathrm{IV}}(\mathrm{bda})(\mathrm{pic})_{2}(\mathrm{OH})\right]^{+}$gave either $\left[\mathrm{Ru}^{\mathrm{IV}}(\mathrm{bda})(\mathrm{pic})_{2}(\mathrm{O}) \cdot\right]^{+}$ $\left(\mathrm{Ru}^{\mathrm{IV}-\mathrm{O}} \cdot\right)$ or $\left[\mathrm{Ru}^{\mathrm{V}}(\mathrm{bda})(\mathrm{pic})_{2}(\mathrm{O})\right]^{+}\left(\mathrm{Ru}^{\mathrm{V}}=\mathrm{O}\right)$ as the key intermediate for bimolecular coupling and single-molecular water nucleophilic attack, respectively. Although we are not able to differentiate between two reaction pathways at the present stage, other methods such as DFT calculations may help us to reveal the detailed mechanism.

\section{Conclusions}

In summary, the photocatalytic activity of bda-based binu- clear ruthenium catalyst $\mathbf{2}$ was investigated in a three-component system and compared with that of its monomeric precursor 1 . It was found that the oxygen evolution activity of both catalysts increased with the amount of $\mathrm{CH}_{3} \mathrm{CN}$ in the phosphate buffer as a result of a larger driving force provided by the photo-activated sensitizer $\left[\mathrm{Ru}(\mathrm{bpy})_{3}\right]^{3+}$. A notable finding here was that the kinetics of the water oxidation reaction by 1 switched from second order to pseudo-first order with the increasing $\mathrm{CH}_{3} \mathrm{CN}$ content. Consequently, the binuclear catalyst 2 showed higher activity when the $\mathrm{CH}_{3} \mathrm{CN}$ content was low, and comparable activities were attained by $\mathbf{1}$ and $\mathbf{2}$ with a high content of $\mathrm{CH}_{3} \mathrm{CN}$. This is probably because the pathway of $\mathrm{O}-\mathrm{O}$ bond formation changes from the bimolecular radical coupling mechanism to the single-site nucleophilic attack of water. This study demonstrates the flexibility of the molecular catalysts in light-driven water oxidation. The solvent-tunable behavior of Ru-bda may also be applicable to electrochemical and photoelectrochemical water oxidation, enabling a deeper understanding and rational design of engineered molecular devices for highly efficient solar water splitting.

\section{Conflicts of interest}

There are no conflicts to declare.

\section{Acknowledgments}

The acknowledgements come at the end of an article after the conclusions and before the notes and references. This research was supported by the National Basic Research Program of China (973 program, 2014CB239402), the National Natural Science Foundation of China (21476043), the Swedish Energy Agency and K\&A Wallenberg Foundation.

\section{References}

[1] S. Berardi, S. Drouet, L. Francàs, C. Gimbert-Suriñach, M. Guttentag, C. Richmond, T. Stoll, A. Llobet, Chem. Soc. Rev., 2014, 43, 7501-7519.

[2] Z. Yu, F. Li, L. C. Sun, Energy Environ. Sci., 2015, 8, 760-775.

[3] Y. Zheng, Z. M. Pan, X. C. Wang, Chin. J. Catal., 2013, 34, 524-535.

[4] F. Li, H. Li, Y. Zhu, J. Du, Y. Wang, L. C. Sun, Chin. J. Catal., 2017, 38, 1812-1817.

[5] X. Q. Du, J. W. Huang, Y. Y. Feng, Y. Ding, Chin. J. Catal., 2016, 37, 123-134.

[6] M. D. Kärkäs, O. Verho, E. V. Johnsto, B. Åkermark, Chem. Rev., 2014, 114, 11863-12001.

[7] H. Dau, C. Limberg, T. Reier, M. Risch, S. Roggan, P. Strasser, ChemCatChem, 2010, 2, 724-761.

[8] A. Kudo, Y. Miseki, Chem. Soc. Rev., 2009, 38, 253-278.

[9] J. H. Yang, D. E. Wang, H. X. Han, C. Li, Acc. Chem. Res., 2013, 46, 1900-1909.

[10] J. R. Ran, J. Zhang, J. G. Yu, M. Jaroniec, S. Z. Qiao, Chem. Soc. Rev., 2014, 43, 7787-7812.

[11] D. L. Ashford, M. K. Gish, A. K. Vannucci, M. K. Brennaman, J. L. Templeton, J. M. Papanikolas, T. J. Meyer, Chem. Rev., 2015, 115, 13006-3049

[12] S. W. Gersten, G. J. Samuels, T. J. Meyer, J. Am. Chem. Soc., 1982, 104, 4029-4030. 


\section{Graphical Abstract}

Chin. J. Catal., 2018, 39: 446-452 doi: 10.1016/S1872-2067(18)63024-4

\section{Visible light-driven oxygen evolution using a binuclear Ru-bda catalyst}

Fei Li *, Congying Xu, Xiaohong Wang, Yong Wang, Jian Du, Licheng Sun

Dalian University of Technology (DUT), China; KTH Royal Institute of Technology, Sweden

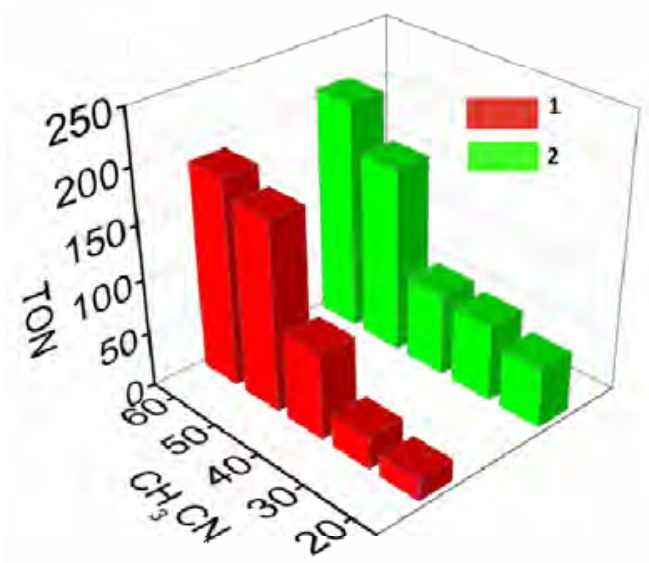

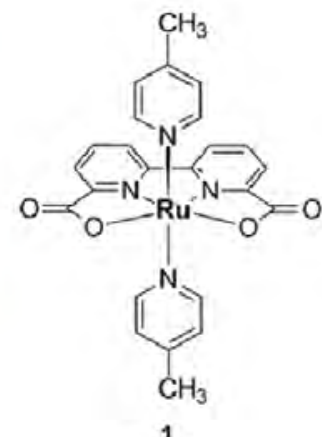

1

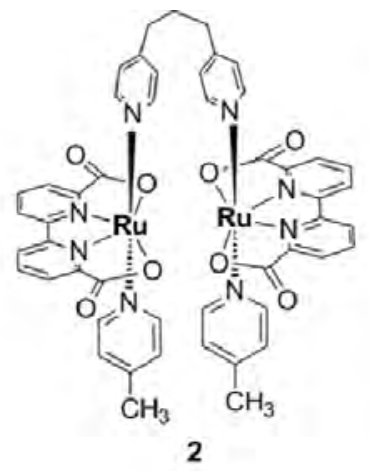

A binuclear ruthenium catalyst exhibited higher activity than its monomeric precursor in photocatalytic water oxidation. However, the difference in the activity between the bi- and mononuclear catalysts was diminished with the increase in the amount of $\mathrm{CH}_{3} \mathrm{CN}_{\text {in }}$ the reaction solution.

[13] R. Cao, W. Z. Lai, P. W. Du, Energy Environ. Sci., 2012, 5, 8134-8157.

[14] L. L. Duan, A. Fischer, Y. H. Xu, L. C. Sun, J. Am. Chem. Soc., 2009, 131, 10397-10399.

[15] J. Nyhlén, L. L. Duan, B. Åkermark, L. C. Sun, T. Privalov, Angew. Chem. Int. Ed., 2010, 49, 1773-1777.

[16] L. L. Duan, F. Bozoglian, S. Mandal, B. Stewart, T. Privalov, A. Llobet, L. C. Sun, Nat. Chem., 2012, 4, 418-424.

[17] Y. Jiang, F. Li, B. B. Zhang, X. N. Li, X. H. Wang, F. Huang, L. C. Sun, Angew. Chem. Int. Ed., 2013, 52, 3398-3401.

[18] D. G. H. Hetterscheid, J. N. H. Reek, Angew. Chem. Int. Ed., 2012, 51, 9740-9747.

[19] L. Wang, L. L. Duan, L. P. Tong, L. C. Sun, J. Catal., 2013, 306, 129-132.

[20] F. Puntoriero, G. La Ganga, A. Sartorel, M. Carraro, G. Scorrano, M. Bonchio, S. Campagna, Chem. Commun., 2010, 46, 4725-472.

[21] Z. Q. Huang, Z. Luo, Y. V. Geletii, J. W. Vickers, Q. S. Yin, D. Wu, Y. Hou, Y. Ding, J. Song, D. G. Musaev, C. L. Hill, T. Q. Lian, J. Am. Chem. Soc., 2011, 133, 2068-2071.
[22] S. Berardi, G. La Ganga, M. Natali, I. Bazzan, F. Puntoriero, A. Sartorel, F. Scandola, S. Campagna, M. Bonchio, J. Am. Chem. Soc., 2012, 134, 11104-11107.

[23] M. R. Norris, J. J. Concepcion, D. P. Harrison, R. A. Binstead, D. L. Ashford, Z. Fang, J. L. Templeton, T. J. Meyer, J. Am. Chem. Soc., 2013, 135, 2080-2083.

[24] N. Kaveevivitchai, R. Chitta, R. F. Zong, M. El Ojaimi, R. P. Thummel, J. Am. Chem. Soc., 2012, 134, 10721-10724.

[25] L. L. Duan, Y. H. Xu, P. Zhang, M. Wang, L. C. Sun, Inorg. Chem., 2010, 49, 209-215.

[26] H. Li, F. Li, B. B. Zhang, X. Zhou, F. S. Yu, L. C. Sun, J. Am. Chem. Soc., 2015, 137, 4332-4335.

[27] S. Berardi, G. La Ganga, M. Natali, I. Bazzan, F. Puntoriero, A. Sartore, F. Scandolal, S. Campagna, M. Bonchio, J. Am. Chem. Soc., 2012, 134, 11104-11107.

[28] L. P. Tong, L. L. Duan, Y. H. Xu, T. Privalov, L. C. Sun, Angew. Chem. Int. Ed., 2011, 50, 445-449.

[29] S. Romain, L. Vigara, A. Llobet, Acc. Chem. Res., 2009, 42, 1944-1953.

\section{基于 Ru-bda 双核钉催化剂的可见光驱动水氧化

\author{
李 斐 ${ }^{a}{ }^{*}$, 徐从英 ${ }^{a}$, 王晓红 ${ }^{a}$, 王 勇 ${ }^{a}$, 杜 健 ${ }^{a}$, 孙立成 ${ }^{a, b}$ \\ a大连理工大学精细化工国家重点实验室, 辽宁大连 116024 \\ 瑞典皇家工学院化学系, 斯德哥尔摩 10044, 瑞典
}

摘要: 开发高效水氧化催化剂对于太阳能分解水制氢和 $\mathrm{CO}_{2}$ 还原都具有重要意义. 我们之前的研究表明, 基于 Ru-bda(bda $=2,2^{\prime}$-联吡定-6,6'二羧酸) 单体的双核钉催化剂在以 $\left(\mathrm{NH}_{4}\right)_{2} \mathrm{Ce}\left(\mathrm{NO}_{3}\right)_{6}$ 为氧化剂的化学法水氧化反应中表现出良好的催化 性能, 比相同条件下单核钓催化剂的活性高出一个数量级. 然而, 该类双核钉催化剂的光催化水氧化性能尚未被系统研究. 
因此我们考察了以丙烷桥双核钓配合物为催化剂、 $\left[\mathrm{Ru}(\mathrm{bpy})_{3}\right] \mathrm{Cl}_{2}$ 为光敏剂、 $\mathrm{Na}_{2} \mathrm{~S}_{2} \mathrm{O}_{8}$ 为电子牺牲体组成的三组分体系的光 催化性能, 并和相应的单核钓催化剂进行了对比, 同时考察了溶液中乙腈的含量对单、双核钓分子催化剂光催化产氧性能 和产氧机理的影响.

实验结果表明, 无论是单核还是双核钓催化剂, 其催化活性与乙腈在磷酸缓冲溶液中的比例密切相关. 乙腈的含量不 仅影响了水氧化的驱动力, 而且影响 O-O 的形成机理, 改变反应的动力学和反应速率. 单、双核钓催化剂的活性都随着乙 腈比例的增加而增加, 然而双核钓催化剂在低乙腈含量的缓冲溶液中展现优于单核钓催化剂的光催化性能; 而在高乙腈 含量的缓冲溶液中, 双核钓催化剂和单核钓催化剂的光催化性能趋于相当. 在最优化条件 (60\% 乙腈) 下, 双核钓的光催化 产氧 TON 值达到 638, 在 $450 \mathrm{~nm}$ 的光量子效率达到 77\%. 我们还发现, 当乙腈浓度较低时, 单核钓催化剂 Ru-bda 催化的 水氧化反应为二级动力学; 当乙腈浓度较高时, 该催化剂在反应中表现为一级动力学. 从而推测 O-O 键的形成机制由双 分子自由基耦合转变成单分子亲核进攻, 也解释了为什么高乙腈含量下单核和双核钓催化剂的活性差别不大. 本研究所 展示的 Ru-bda 的溶剂效应可能同样适用于电化学和光电化学水氧化, 对深入理解和设计高效太阳能分解水器件具有重要 意义.

关键词: 水氧化; 双核钓催化剂; 光催化; 溶剂效应; 动力学

收稿日期: 2017-10-17. 接受日期: 2018-01-06. 出版日期: 2018-03-05.

*通讯联系人. 电话: (0411)84986247; 传真: (0411)84986245; 电子信箱: lifei@dlut.edu.cn

基金来源：国家重点基础研究发展计划 (973 计划, 2014CB239402); 国家自然科学基金 (21476043); 中央高校基本科研业务费 (DUT17ZD204).

本文的电子版全文由Elsevier出版社在ScienceDirect上出版(http://www.sciencedirect.com/science/journal/18722067). 